\title{
Molecular Cloning of the Shv-1 $\beta$-Lactamase Gene and Construction of an Shv-1 Hybridization Probe
}

\author{
By UMI BISESSAR† AND RICHARD JAMES* \\ School of Biological Sciences, University of East Anglia, Norwich, Norfolk NR4 7TJ, UK
}

(Received 17 August 1987; revised 13 October 1987)

\begin{abstract}
We have cloned the Shv-1 $\beta$-lactamase gene from the R1010 plasmid into pACYC184. By subcloning and transposon mutagenesis we have localized the gene to a $1.6 \mathrm{~kb} \mathrm{BscI}-\mathrm{Sall}$ fragment of R1010, which is present in the recombinant plasmid pUB8. A $900 \mathrm{bp}$ Pst fragment of pUB8 was shown to be a specific hybridization probe by testing against plasmids which encode 17 different $\beta$-lactamase enzymes. A comparison was made of the sensitivity of the Shv-1 probe labelled with either $\left[{ }^{35} \mathrm{~S}\right] \mathrm{dCTP}$ or with photobiotin.
\end{abstract}

\section{INTRODUCTION}

The increasing incidence of resistance of Gram-negative bacteria, especially those involved in hospital-acquired infection, to $\beta$-lactam antibiotics is principally due to the production of $\beta$ lactamase enzymes which inactivate the antibiotics (Medeiros, 1984). Hospital-acquired infection is a leading cause of death in hospitalized patients. Measures to reduce the spread of hospital-acquired infection are critically dependent upon rapid, reliable and relatively cheap methods for the detailed epidemiological investigation of clinical isolates. A variety of methods have been used to classify $\beta$-lactamases in clinical isolates, including substrate profiles, inhibition studies, isoelectric points and molecular mass determinations (Matthew, 1979). An alternative method of identification has been described based upon Relative Substrate Affinity Index values (James, 1983), which has been modified by other workers (Eliasson \& Kamme, 1985), but the most commonly used method is that of isoelectric focussing of cell extracts in parallel with $\beta$-lactamase reference enzymes (Matthew \& Harris, 1976; Medeiros, 1984; Simpson et al., 1986). The increasing number of $\beta$-lactamase enzymes which have now been characterized, some of which have very similar isoelectric points (Medeiros, 1984), require a combination of tests for satisfactory identification. This is inappropriate for widespread clinical use. Limited surveys of the incidence of $\beta$-lactamase enzymes in clinical isolates, many of which were done before the recent large increase in the number of characterized enzymes, have shown that the most common are Tem-1, Tem-2, Shv-1 and Oxa-1 (Matthew, 1979; Simpson et al., 1980, 1986; Stobberingh et al., 1982; Roy et al., 1983; Medeiros, 1984; Levy et al., 1985).

In order to monitor the emergence of 'new' $\beta$-lactamases, and to facilitate the epidemiological investigation of hospital-acquired infection involving $\beta$-lactam-resistant isolates, gene probes against $\beta$-lactamase enzymes appear to offer the most promise. DNA probes against the Tem-1 (Cooksey et al., 1985; Levesque et al., 1987; Ouellette et al., 1987), the Oxa-1 (Ouellette \& Roy, 1986; Levesque et al., 1987) and the Rob-1 and Pse-1 $\beta$-lactamase genes (Levesque et al., 1987) have been prepared. Here we describe the molecular cloning of the Shv-1 gene and the development of a non-radioactive Shv-1 gene probe.

† Present address: John Innes Institute, Norwich, Norfolk, UK. 


\section{METHODS}

Bacterial strains and media. Escherichia coli JM83 hsdR, a restriction deficient derivative of E. coli JM83 (Ara- $\mathrm{Lac}^{-} \mathrm{Pro}^{-} \mathrm{Thi}^{-} \mathrm{rpsL} \phi 80 \mathrm{~d}$ lacZM15), was the host for all transformations. It was grown at $37^{\circ} \mathrm{C}$ with shaking in LB medium (Miller, 1972), supplemented where appropriate with ampicillin $\left(100 \mu \mathrm{g} \mathrm{ml}^{-1}\right)$, or chloramphenicol (15 $\left.\mu \mathrm{g} \mathrm{ml}^{-1}\right)$.

Plasmids. The R 1010 plasmid which encodes the Shv-1 $\beta$-lactamase was described by Nugent \& Hedges (1979). The cloning vector pUC18 (Vieira \& Messing, 1982) was purchased from Pharmacia. The cloning vector pACYC184, which encodes chloramphenicol and tetracycline resistance was described by Chang \& Cohen (1978). The $E$. coli $\mathbf{C} 600$ derivatives which contain plasmids determining 17 different $\beta$-lactamase types (Jacoby $\&$ Sutton, 1985) were kindly supplied by G. A. Jacoby (Massachusetts' General Hospital, USA), and were the source of reference $\beta$-lactamase enzymes. Plasmids were prepared by a modification of the method of Birnboim \& Doly (1979).

Enzymes and reagents. Restriction enzymes and T4 DNA ligase were purchased from Anglian Biotechnology, Gibco-BRL, Pharmacia or Boehringer. Nitrocefin, a chromogenic substrate of $\beta$-lactamase enzymes (O'Callaghan et al., 1972), was purchased from Oxoid and was used following the supplier's recommendations.

Plasmid restriction, ligation, transformations and electrophoresis. Digestion of DNA with restriction endonucleases, ligation of DNA fragments, and transformation of competent cells were done as described by Maniatis $e t$ al. (1982). Electrophoresis of DNA fragments was done as previously described (Chak \& James, 1984), and specific fragments were recovered from low melting point agarose gels for the labelling of DNA probes.

Transposon mutagenesis. Transposon mutagenesis of plasmid pUB8 with Tn 1000 was done as previously described (Chak \& James, 1984), after transferring the target recombinant plasmid into $E$. coli RB308. After conjugation with $E$. coli RB85, transconjugant colonies were selected on LB agar plates containing streptomycin $\left(200 \mu \mathrm{g} \mathrm{ml}^{-1}\right)$ and chloramphenicol $\left(15 \mu \mathrm{g} \mathrm{ml}^{-1}\right)$. The resulting colonies were then screened for sensitivity to ampicillin $\left(50 \mu \mathrm{g} \mathrm{ml}^{-1}\right)$. Transposon insert sites were located by isolating plasmid DNA from AMPS colonies and restricting separately with EcoRI, BamHI or HindIII (Guyer, 1978).

Isoelectric focussing. Isoelectric focussing was done by a modification of the method of Matthew et al. (1975), using Ampholine PAG plates with a pH range of 3.5 to 9.5 purchased from LKB. Isoelectric point markers (BDH) and $\beta$-lactamase standard enzymes were run in parallel tracks of all gels to allow the accurate identification of the Shv-1 $\beta$-lactamase. Cell extracts for isoelectric focussing were prepared by sonication.

Labelling of the Shv-1 gene probe. Specific fragments to be used as gene probes were labelled using $\left[{ }^{35}\right.$ S $] \mathrm{dCTP}$ by using a Multiprime kit (Amersham), or by using photobiotin acetate (Vector Laboratories). With either label the manufacturers' protocols were followed.

Hybridization. Plasmids for hybridization against the Shv-1 gene probes were Southern-blotted onto nitrocellulose filters and then pre-hybridized and hybridized, in the absence of formamide, follwing the procedure of Mason \& Williams (1985). After hybridization overnight at $65^{\circ} \mathrm{C}$, the filters were washed in $2 \times \mathrm{SSC} / 0.1 \%$ SDS, $0.2 \times \mathrm{SSC} / 0.1 \% \mathrm{SDS}$, and finally in $0.15 \times \mathrm{SSC} / 0.1 \% \mathrm{SDS}$ at $65^{\circ} \mathrm{C}$ before drying. $(1 \times \mathrm{SSC}$ is $0 \cdot 15 \mathrm{M}-\mathrm{NaCl}$, $0.015 \mathrm{M}$-trisodium citrate/citric acid, $\mathrm{pH} 7 \cdot 0$.)

\section{RESULTS AND DISCUSSION}

\section{Cloning of the Shv-1 gene}

The R1010 plasmid which encodes the Shv-1 $\beta$-lactamase is $89 \mathrm{~kb}$ in size (Nugent \& Hedges, 1979). After restriction of $\mathrm{R} 1010$ with $B a m H I$ and ligation with pACYC184 restricted with $B a m \mathrm{HI}$, the ligated DNA was transformed into competent cells of $E$. coli JM83 hsdR, with selection for CMPR AMPR transformants. Plasmid pUB3 was isolated from a transformant colony and was shown by restriction mapping to consist of a $6.6 \mathrm{~kb}$ Bam HI fragment of R1010 and the $4.2 \mathrm{~kb}$ pACYC1 84 vector. A restriction map was constructed of recombinant plasmid pUB3 (Fig. 1). This plasmid conferred resistance to $500 \mu \mathrm{g}$ ampicillin $\mathrm{ml}^{-1}$ on E. coli JM83 $h s d R$. Using isoelectric focussing, cell extracts prepared from $E$. coli JM83 $h s d R$ carrying pUB3 were shown to contain the Shv-1 $\beta$-lactamase, unlike extracts prepared from this strain carrying pACYC184 alone. In an attempt to localize the position of the Shv-1 gene we constructed subclones of pUB3 (Fig. 1). Deletion of a $1.5 \mathrm{~kb} \mathrm{BscI}$ fragment of pUB3, from a $B s c \mathrm{I}$ site in the vector, to the single $B s C I$ site in the insert fragment, gave rise to a recombinant plasmid, pUB6, which still encoded ampicillin resistance. The presence of the Shv-1 $\beta$-lactamase in cell extracts of E. coli JM83 carrying pUB6 was confirmed by isoelectric focussing. Removal of a $4.1 \mathrm{~kb}$ SalI fragment of pUB6, from a $S a l I$ site in the vector to the single $S a l l$ site in the insert fragment, gave rise to the recombinant plasmid pUB8, which also still encoded the Shv-1 $\beta$-lactamase. 


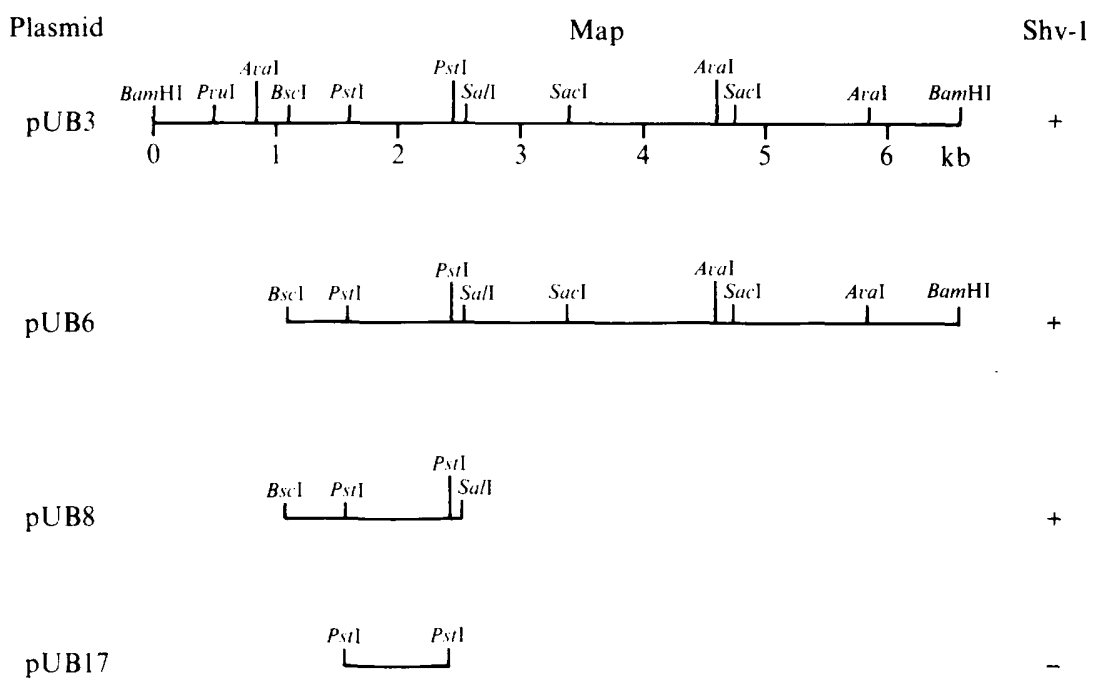

Fig. 1. Subcloning and transposon mutagenesis of the R1010 plasmid. The restriction fragments present in the plasmids listed are indicated (for clarity the vector sequences are not shown), together with the phenotype with respect to the production of the Shv-1 $\beta$-lactamase.

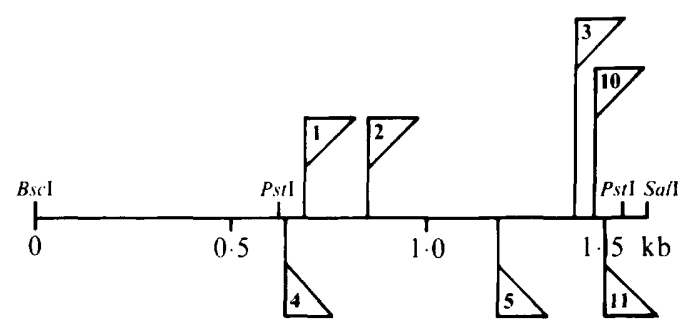

Fig. 2. Tn 1000 transposon insertion sites in the $1.6 \mathrm{~kb} \mathrm{BscI-Sall}$ fragment of pUB8 which inactivate the Shv-1 $\beta$-lactamase gene.

Subcloning of the $900 \mathrm{bp}$ PstI fragment of pUB8 into the vector pUC18 restricted with PstI resulted in the recombinant plasmid pUB17. Although this recombinant plasmid conferred ampicillin resistance, due to the Tem-1 $\beta$-lactamase gene present in the vector pUC18 (Vieira \& Messing, 1982), the absence of the Shv-1 $\beta$-lactamase was confirmed by isoelectric focussing of cell extracts. Reversing the orientation of the $900 \mathrm{bp}$ PstI fragment, with respect to the pUC18 lac promoter, did not result in the synthesis of the Shv-1 $\beta$-lactamase. No useful restriction sites were found in the $900 \mathrm{bp} P s t \mathrm{I}$ fragment; this prevented further deletion cloning of this fragment.

\section{Transposon mutagenesis of $p U B 8$}

In order to obtain more precise information on the localization of the Shv-1 gene we performed Tn 1000 transposon mutagenesis of plasmid pUB8. From 450 colonies we identified $32 \mathrm{CMP}^{\mathrm{R}} \mathrm{AMPS}$ transconjugants and subsequently mapped seven different $\mathrm{Tn} 1000$ insertion sites which inactivated the Shv-1 gene (Fig. 2). From the insert sites of number 4 and number 11 , the minimum size of the $S h v-1$ gene and its regulatory elements is $850 \mathrm{bp}$. This size of DNA fragment has a coding capacity for a 30000 Da protein, which is in good agreement with the reported molecular mass of the purified Shv-1 $\beta$-lactamase of $27500 \mathrm{Da}$ (Barthelemy et al., 1986), but not with the value of 17000 Da quoted in Matthew (1979). 
Table 1. Hybridization studies against 17 plasmid-encoded $\beta$-lactamases

$E$. coli $\mathrm{C} 600$ carrying the plasmid indicated was hybridized with either the ${ }^{35} \mathrm{~S}$-labelled, or the biotinlabelled, Shv-l probe. + , Positive hybridization signal; - , no hybridization; $(-)$, hybridization signal with lower stringency post-hybridization washes.

\begin{tabular}{|c|c|c|c|c|c|c|c|}
\hline \multirow[b]{2}{*}{$\beta$-Lactamase } & \multirow[b]{2}{*}{ Plasmid } & \multicolumn{2}{|c|}{ Probe labelled with } & \multirow[b]{2}{*}{$\beta$-Lactamase } & \multirow[b]{2}{*}{ Plasmid } & \multicolumn{2}{|c|}{ Probe labelled with } \\
\hline & & ${ }^{35} \mathrm{~S}$ & Biotin & & & ${ }^{35} \mathrm{~S}$ & Biotin \\
\hline None & None & - & - & Oxa-3 & $\mathrm{pUZ8}:: \operatorname{Tn} 1411$ & - & - \\
\hline Tem-1 & pMK $20:: \operatorname{Tn} 3$ & - & - & Oxa-4 & pMG203 & - & - \\
\hline Tem-2 & RP4 & - & - & Oxa-5 & pMG54 & - & - \\
\hline Shv-1 & R1010 & + & + & Oxa-6 & pUZ8-pMG39 & - & - \\
\hline Lcr-1 & pUZ8:: $\operatorname{Tn} 1412$ & $(-)$ & - & Oxa-7 & pMG202 & - & - \\
\hline Cep-1 & pNU104 & $(-)$ & - & Pse-1 & pCR $1:: \operatorname{Tn} / 40 I$ & - & - \\
\hline Hms-1 & R997 & - & - & Pse-2 & pUZ8-RI51 & - & - \\
\hline Carb-3 & pUZ8::Tn1408 & - & - & Pse- 3 & $\mathrm{Rms} 149$ & - & - \\
\hline Oxa-1 & pMK $20:: \operatorname{Tn} 2603$ & - & - & Pse-4 & pUZ8-DAL & - & - \\
\hline Oxa-2 & R46 & $(-)$ & $(-)$ & & & & \\
\hline
\end{tabular}

\section{Construction of Shv-1 gene probe}

In view of our results that the Shv-1 gene accounts for more than $80 \%$ of the DNA in the $900 \mathrm{bp}$ Pst I fragment of pUB8 (Fig. 1), we decided to use this fragment purified from the highcopy-number recombinant plasmid pUB17 as a hybridization probe. Since there is the possibility of false hybridization signals from transposon-like sequences located adjacent to the Shv-1 gene, a situation previously encountered with a gene probe against the Tem-1 $\beta$-lactamase (Cooksey et al., 1985), we determined the specificity of the Shv-l gene probe against plasmid preparations made from $17 \mathrm{E}$. coli $\mathrm{C} 600$ cultures carrying different plasmid-coded $\beta$-lactamases (Jacoby \& Sutton, 1985). Although ${ }^{32} \mathrm{P}$ is routinely used as the label for hybridization probes in research laboratories, and has been used to label a Tem-1 gene probe for clinical use (Ouellette $e t$ al., 1987), we feel that most laboratories will be unable to use ${ }^{32} \mathrm{P}$-labelled probes because of the considerable regulatory and practical problems associated with high-energy isotopes. For this reason we decided to label the Shv-1 probe with the lower-energy isotope ${ }^{35} \mathrm{~S}$ and with photobiotin.

The results showed that, at the high stringency used for the post-hybridization washes, both the ${ }^{35} \mathrm{~S}$ - and the biotin-labelled probe only hybridized with the R1010 plasmid (Table 1). If the post-hybridization washes were done with $2 \times \operatorname{SSC} / 0 \cdot 1 \% \operatorname{SDS}$ at $42^{\circ} \mathrm{C}$, then a signal was seen with the plasmids encoding the Lcr-1, the Cep-1 and the Oxa- $2 \beta$-lactamases with the ${ }^{35} \mathrm{~S}$ labelled probe, and with the Oxa-2 plasmid when using the biotin-labelled probe. We believe that the difference between the two reflects the difference in sensitivity between radioactively labelled and biotin-labelled probes. These results imply some degree of homology between the probe DNA and a nucleotide sequence on these plasmids, though the homologous sequence may not, of course, be the coding region of the $\beta$-lactamase. We are investigating the degree of homology between these $\beta$-lactamases by molecular cloning and DNA sequencing.

The Shv-1 gene probe also gave hybridization signals against plasmids present in three clinical isolates of $E$. coli, which had been shown by isoelectric focussing to produce the Shv-1 $\beta$ lactamase, and with chromosomal DNA from 13 out of 14 clinical isolates of Klebsiella pneumoniae (Bisessar, 1986). This last result provides support for the suggestion that the Shv-1 gene evolved from the chromosomal $\beta$-lactamase of Klebsiella (Nugent \& Hedges, 1979). No hybridization signals were seen with 20 clinical isolates which produced $\beta$-lactamases other than Shv-1.

\section{Conclusions}

We have demonstrated a method for the preparation of a specific Shv-1 $\beta$-lactamase gene probe which does not rely on nucleotide sequencing data. It has been reported that the sensitivity of detection of biotin-labelled probes is a factor of 4-8 lower than that of equivalent 
Table 2. Comparison of ${ }^{35} S$-labelled and biotin-labelled probes

$\begin{array}{ccccc}\begin{array}{c}\text { Probe labelled } \\ \text { with: }\end{array} & \begin{array}{c}\text { Half- } \\ \text { life }\end{array} & \begin{array}{c}\text { DNA required } \\ \text { for labelling }\end{array} & \begin{array}{c}\text { Time before } \\ \text { hybridization* }\end{array} & \begin{array}{c}\text { Time after } \\ \text { hybridization } \dagger\end{array} \\ { }^{35} \mathrm{~S} & 78 \mathrm{~d} & 25 \mathrm{ng} & 2 \mathrm{~d} & >3 \mathrm{~d} \\ \text { Biotin } & >12 \text { months } & >1 \mu \mathrm{g} & 2 \mathrm{~d} & 6 \mathrm{~h}\end{array}$

* Time required to prepare DNA samples from colonies, run a gel and do a Southern blot.

$\dagger$ Time required after hybridization before results are obtained. The use of ${ }^{32} \mathrm{P}$ instead of ${ }^{35} \mathrm{~S}$ could shorten the post-hybridization time to $5 \mathrm{~h}$.

${ }^{32}$ P-labelled probes (Bialkowska-Hobrzanska, 1987). It is apparent from our study that the sensitivity of the biotin-labelled Shv-1 probe is sufficient for clinical use. In our experience, the relative advantages and disadvantages of using radioactively labelled or biotin-labelled probes are as summarized in Table 2 . A radioactively labelled gene probe against the Tem-1 $\beta$ lactamase has been used to screen 328 clinical isolates for the presence of the Tem-1 gene and the results compared with isoelectric focussing (Jouvenot et al., 1987). The results obtained with both methods were concordant in $92.7 \%$ of the isolates. These authors hybridized their probe with colonies growing directly on nitrocellulose filters placed on MacConkey agar plates. This removes the need for the preparation of cell lysates and allows the screening of a large number of colonies; however, the total time before obtaining a result is $3 \mathrm{~d}$.

One potential problem with the use of an Shv-l probe for direct colony blotting is that this method cannot readily distinguish between plasmid or chromosomally encoded $\beta$-lactamase genes, whereas the resulting phenotype, in terms of the level of $\beta$-lactam resistance, may be considerably different due to the gene dosage effect. It may therefore be necessary to construct oligonucleotide probes specific for the two genes. A biotin-labelled probe has been used directly with colonies growing on agar plates to detect enteroinvasive $E$. coli. In order to prevent nonspecific hybridization signals extensive treatment of the hybridization filters with proteinase $\mathrm{K}$ was required before hybridization (Sethabutr et al., 1985). Compared with antibiotic sensitivity testing $\beta$-lactamase gene probe technology therefore appears to offer little to assist rational therapy; however, it would obviously generate considerable information of great value for epidemiological investigations. The combined value of antibiotic sensitivity data, $\beta$-lactamase gene probe data and species identification would be of great value in generating a data base of information with considerable predictive value for antibiotic therapy.

We wish to acknowledge the financial support and facilities offered by Pfizer, Sandwich, UK, and for the constructive advice and criticism of this work offered by Brian Moore. U. B. was the recipient of an SERC CASE studentship.

\section{REFERENCES}

Barthelemy, M., Peduzzi, J., Verchere-Beaur, C., Yaghlane, H. B. \& Labia, R. (1986). Purification and biochemical properties of Pitton's type 2 betalactamase (SHV-1). Annales de l'Institut Pasteur 137, 19-27.

Bialkowska-HobrzansKa, H. (1987). Detection of enterotoxigenic Escherichia coli by dot blot hybridization DNA probes. Journal of Clinical Microbiology 25, 338-343.

Birnborm, H. C. \& Doly, J. (1979). A rapid alkaline extraction procedure for screening plasmid DNA. Nucleic Acids Research 7, 1513-1523.

BISESSAR, U. (1986). $\beta$-Lactam resistance amongst the Enterobacteriaceae. PhD thesis, University of East Anglia, Norwich, UK.

CHAK, K.-F. \& JAMES, R. (1984). Localization and characterization of a gene on the ColE3-CA38 plasmid that confers immunity to colicin E8. Journal of General Microbiology 130, 701-710.
Chang, A. C. Y. \& Cohen, S. N. (1978). Construction and characterization of amplifiable multicopy DNA cloning vehicles derived from the P15A cryptic miniplasmid. Journal of Bacteriology 134, 1141-1156. CoOksey, R. C., Clark, N. C. \& Thornsberry, C. (1985). A gene probe for Tem-1 type $\beta$-lactamase. Antimicrobial Agents and Chemotherapy 23, 154 156.

Eliasson, I. \& Kammes, C. (1985). Characterisation of the plasmid-mediated $\beta$-lactamase in Branhamella catarrhalis with special reference to substrate affinity. Journal of Antimicrobial Chemotherapy 15, 139149.

GUYeR, M. S. (1978). The $\gamma \delta$ sequence of $F$ is an insertion sequence. Journal of Molecular Biology 126, 347-365.

JACOBY, G. A. \& SUTTON, L. (1985), $\beta$-Lactamases and $\beta$-lactam resistance in E. coli. Antimicrobial Agents and Chemotherapy 28, 703-705. 
JAMES, R. (1983). Relative substrate affinity index values: a method for identification of beta-lactamase enzymes and prediction of successful beta-lactam therapy. Journal of Clinical Microbiology 17, 791-798.

Jouvenot, M., Deschaseaux, M. L., RoyeX, M., Mougin, C., Cooksey, R. C., Michel-Briand, Y. \& ADESSI, G. L. (1987). Molecular hybridization versus isoelectric focussing to determine Tem-type $\beta$ lactamases in Gram-negative bacteria. Antimicrobial Agents and Chemotherapy 31, 300-305.

Levesque, R. C., Medeiros, A. A. \& Jacoby, G. A. (1987). Molecular cloning and DNA homology of plasmid-mediated $\beta$-lactamase genes. Molecular and General Genetics 206, 252-258.

Levy, S. B., Hedges, R. W., Sullivan, F., Medeiros, A. A. \& Sosroseputro, H. (1985). Multiple antibiotic resistance plasmids in Enterobacteriaceae isolated from diarrhoeal specimens of hospitalized children in Indonesia. Journal of Antimicrobial Chemotherapy 16, 7-16.

Maniatis, T., Fritsch, E. F. \& Sambrook, J. (1982). Molecular Cloning: a Laboratory Manual. Cold Spring Harbor, NY: Cold Spring Harbor Laboratory.

Mason, P. J. \& Williams, J. G. (1985). Hybridization in the analysis of recombinant DNA. In Nucleic Acid Hybridization: a Practical Approach, pp. 113-138. Edited by B. D. Hames \& S. J. Higgins. Oxford: IRL Press.

MatTHEw, M. (1979). Plasmid mediated $\beta$-lactamases of Gram-negative bacteria. Properties and distribution. Journal of Antimicrobial Chemotherapy 5, 349358.

MATTHEW, M. \& HARRIS, A. M. (1976). Identification of $\beta$-lactamases by analytical isoelectric focusing: correlation with bacterial taxonomy. Journal of General Microbiology 96, 55-67.

Matthew, M., Harris, A. M., Marshall, M. J. \& Ross, G. W. (1975). The use of analytical isoelectric focusing for detection and identification of $\beta$ lactamases. Journal of General Microbiology 88, 169178.

Medeiros, A. A. (1984). $\beta$-Lactamases. British Medical Bulletin 40, 18-27.

Miller, J. H. (1972). Experiments in Molecular Genetics. Cold Spring Harbor, NY: Cold Spring Harbor Laboratory.
Nugent, M. \& Hedges, R. W. (1979). The nature of the genetic determinant for the Shv-1 $\beta$-lactamase. Molecular and General Genetics 175, 239-243.

O'Callaghan, C. H., Morris, A., Kirby, S. M. \& SHINGLER, A. H. (1972). Novel method for detection of $\beta$-lactamases by using a chromogenic cephalosporin substrate. Antimicrobial Agents and Chemotherapy 1, 283-288.

OUelletTE, M. \& RoY, P. H. (1986). Analysis by using DNA probes of the Oxa-1 $\beta$-lactamase gene and its transposon. Antimicrobial Agents and Chemotherapy 30, $46-51$

Ouellette, M., Rossi, J. J., Bazin, R. \& Roy, P. H. (1987). Oligonucleotide probes for the detection of Tem- 1 and Tem-2 $\beta$-lactamase genes and their transposons. Canadian Journal of Microbiology 33, 205-211.

Roy, C., Foz, A., Segura, C., Tirado, M., Fuster, C. \& REIG, R. (1983). Plasmid determined $\beta$-lactamases identified in a group of 204 ampicillin-resistant Enterobacteriaceae. Journal of Antimicrobial Chemotherapy 12, 507-510.

Sethabutr, O., Hanchalay, S., Echeverria, P., TAYLOR, D. N. \& LEKSOMBOON, U. (1985). A nonradioactive DNA probe to identify Shigella and enteroinvasive Escherichia coli in stools of children with diarrhoea. Lancet 1095-1097.

Simpson, I. N., Harper, P. B. \& O'Callaghan, C. H (1980). Principle $\beta$-lactamases responsible for resistance to $\beta$-lactam antibiotics in urinary tract infections. Antimicrobial Agents and Chemotherapy 17, 927-936.

Simpson, I. N., Knothe, H., Plested, S. J. \& HaR Per, P. B. (1986). Qualitative and quantitative aspects of $\beta$-lactamase production as mechanisms of $\beta$-lactam resistance in a survey of clinical isolates from faecal samples. Journal of Antimicrobial Chemotherapy 17, 725-737.

Stobberingh, E. E., Houben, A. W. \& Van Boven, C. P. A. (1982). Distribution and characterisation of $\beta$ lactamase producing strains isolated in the southern part of the Netherlands. Current Chemotherapy and Immunotherapy 1, 747-748.

VieIRA, J. \& MEssing, J. (1982). The pUC plasmids, an M13 mp-7 derived system for insertion mutagenesis and sequencing with synthetic universal primers. Gene 19, 259-268. 